Jap. J. M. Sc. \& Biol., 17, 13-22, 1964

\title{
THE STABILIZING EFFECT OF L-CYSTINE ON THE THERMAL INACTIVATION OF POLIOVIRUS
}

\section{ROLE OF L-CYSTINE ON THE STABILIZATION OF POLIOVIRUS AGAINST HEAT-INACTIVATION AND ON THE SELECTION OF THERMOSTABLE MUTANTS*}

\author{
NoBUKo IKEGAMI, EIKo YOSHIKAWA \\ AND ISAMU TAGAYA \\ Department of Enteroviruses, National Institute of Health, Tokyo
}

(Received: December 10th, 1963)

In the previous publication (Ikegami et al., 1963) it was reported that the rate of the stabilizing effect of L-cystine on various strains belonging to the same immunogenic type was different from each other, and that the difference of the rate was a rather stable genetic entity, which remained unchanged after human passages of the vaccine virus, suggesting its applicability for the differentiation of the vaccine-derived strains of types 1 and 2 polioviruses from wild ones.

The present communication deals with the results of two kinds of experiments aimed at elucidating the mechanism of the effect of L-cystine on poliovirus. One concerns the experimental data that would give support to the hypothesis that the stabilizing effect of cystine on poliovirus results from the combination of the compound with the protein portion of the virus particle. The other concerns the relationship between the existence of L-cystine and the selection of thermoresistant poliovirus variants, by alternating heating and passages of virus in monkey kidney tissue cultures.

\section{MATERIALS AND METHODS}

Tissue culture and media: MS ("monkey-stable") cell line** was grown in continuous culture in Earle's salt solution supplemented with $0.5 \%$ lactalbumin hydrolysate, $0.1 \%$ yeast extract and $10 \%$ calf serum, and its bottle cultures were used for the assay of infectious RNA extracted from poliovirus.

The preparation of primary monkey kidney cell cultures and of a modified 199 synthetic medium deprived of five nutritious components (L-cystine, L-cysteine, L-glutathione, L-tyrosine and ascorbic acid) - to be referred to as cystine-free 199 medium - was described elsewhere (Ikegami et al., 1963).

Virus: Type 1 poliovirus strains, Mahoney and LSc, 2ab (Sabin), were employed in the present experiments. Plaque-purified virus of both strains was propagated in monkey kidney cells in cystine-free 199 medium, and the pooled infected tissue culture fluid was used as a stock virus.

Cystine: The preparation method of L-cystine stock solution was described elsewhere (Ikegami

* This report was presented in part at the Annual Meeting of the Japanese Association of Virologists, Tokyo, October 26, 1962.

** Sent to our Institute in 1953 from Dr. R. W. Brown, The George Washington Carver Foun.

dation, Tuskegee Institute, Alabama, U. S. A.

池上信子・吉川映子・多ヶ谷勇（国立予防衛生研究所腸内ウイルス部） 
et al., 1963).

Extraction of infectious RNA : Extraction of infectious RNA from the stock virus of Mahoney strain was carried out after the procedures described by Alexander et al. (1958) and Holland et al. (1960). Prior to extraction, virus was diluted with an equal amount of $0.02 \mathrm{M}$ phosphate buffer of $\mathrm{pH} 7.2$, supplemented with $5 \times 10^{-4} \mathrm{M}$ EDTA and $10^{-2} \mathrm{M}$ Tris-(hydroxy methyl)-aminomethane (tris buffer), and then an equal amount of cold water-saturated phenol was added to the diluted virus-suspension in a rubber-stoppered tube. The mixture was shaken by hand vigorously for 8 minutes while being cooled with ice water. After the centrifugation of the mixture at 4,000 r. p. m. for 5 minutes, the water phase was transferred to another tube containing an equal amount of cold water-saturated phenol. The mixture was again shaken vigorously for 4 minutes and then was spun. Three successive extractions with phenol were carried out.

The phenol remained in the last water phase was removed by four successive extractions with an equal amount of peroxide-free ethylether, and the residual ether was removed by bubbling nitrogen gas through the aqueous extract for 5 minutes.

Assay of the infectivity of RNA preparation and intact virus: Four days culture of MS cell monolayers was used for the assay of the infectivity of RNA preparation and intact virus. The culture fluid was removed from the monolayers and the cells were washed twice with $5 \mathrm{cc}$ per bottle of phosphate buffered saline. RNA preparations or intact virus suspensions were diluted 10 times into $2 \mathrm{M} \mathrm{MgSO}_{4}$ (further dilutions were also made with $2 \mathrm{M} \mathrm{MgSO}_{4}$ ) just before inoculation. The MS cell monolayers inoculated with $0.2 \mathrm{cc}$ of either diluted RNA or intact virus were incubated at $36^{\circ} \mathrm{C}$ for 20 minutes for absorption. After the absorption period, the monolayers were immediately washed twice with phosphate-buffered saline and then they were overlaid with $3 \mathrm{cc}$ per bottle of agar medium, which consisted of Earle's salt solution supplemented with $0.5 \%$ lactalbumin hydrolysate, $0.1 \%$ yeast extract, $0.11 \%$ bovine albumin fraction $\mathrm{V}$ and $1.5 \%$ agar. On the third day of incubation at $36^{\circ} \mathrm{C}$, the second overlay was made with $2 \mathrm{cc}$ per bottle of the agar medium added with 1:50,000 neutral red. Several hours later, usually after 6 to 7 hours, visible plaques were counted. They were reread on the fourth day.

Serial passages of the survival fraction of the virus after heating at $50^{\circ} \mathrm{C}$ with or without cystine in monkey kidney cultures: The stock virus was divided into two portions, of which one was mixed with L-cystine at the concentration of $50 \mu \mathrm{g}$ per cc (cystine group) and the other was mixed with tris buffer (cystine-free group). They were incubated at $37^{\circ} \mathrm{C}$ for 12 hours to stabilize the virus of the cystine group, and then were heated at $50^{\circ} \mathrm{C}$ for 6 hours. The survival fractions thus obtained were grown in monkey kidney cell cultures. The cultures infected with the virus of the cystine group were maintained with the modified 199 medium supplemented with only cystine at a concentration of $50 \mu \mathrm{g}$ per $\mathrm{cc}$ and those infected with the virus of the cystinefree group were maintained with cystine-free 199 medium. The cells and medium were harvested when the maximal CPE was observed, underwent one cycle of freezing and thawing and the supernates after a light centrifugation were designated as S-h-1p-cys $(+)$ and S-h-1p-cys $(-)$, respectively. These virus suspensions were again treated in an identical manner as described above and the second survivors were obtained. Ten serial selective passages were thus carried out and S-h-10p-cys $(+)$ and S-h-10p-cys $(-)$ were obtained. No limiting dilution passages or plaque purification were carried out throught the passages.

Test for thermal stability of virus by cystine: Some of the progenies obtained during the serial passages described above were propagated in the monkey kidney cell cultures maintained with cystine-free 199 medium and the harvests were examined for their thermal stability in the presence of different concentrations of cystine. The procedure has been described in detail in the previous communication (Ikegami et al., 1963).

$d$ marker test and rct/40 marker test: The $\mathrm{d}$ marker test was carried out as described previously (Ikegami et al., 1963). The reproduction capacity of virus at a high temperature was measured in a water bath regulated at $40.15^{\circ} \mathrm{C} \pm 0.05^{\circ} \mathrm{C}$ using tube cultures of monkey kidney cells.

\section{EXPERIMENTAL RESULTS}

\section{Assay of Infectious RNA Extracted from Heated Poliovirus}

Concerning the mechanism of the stabilizing effect of L-cystine against the thermal inactivation of poliovirus, Pohjanpelto (1958) has proposed an assumption in her early 
report that L-cystine seemed to combine with the viral protein and to play part in the protection of the virus particle from the change in steric configuration of the virus protein. If this is the case, it would be reasonable to presume that the level of infectivity of RNA preparation extracted from poliovirus heated in the presence of cystine may be the same as that of infections RNA from unheated virus.

The experiments were designed as follows. Type 1 Mahoney strain was chosen for this experiment, because of its comparatively higher efficiency of plaque formation on MS cells than that on primary monkey kidney cells, while the former cell is more suitable for the assay of infectious RNA. Stock virus was mixed with an equal volume of cystine solution to make the final concentration of the compound $100 \mu \mathrm{g}$ per cc. As a cystineless control, virus was mixed with an equal amount of tris buffer. After incubation of both mixtures at $37^{\circ} \mathrm{C}$ for 12 hours, each mixture was divided into two portions. One of each mixture was heated at $50^{\circ} \mathrm{C}$ for intervals specified in Table 1 , and the other served as the unheated control. An aliquot taken from the unheated or heated sample

Table 1. Extraction of infections RNA from heated viruses with and without L-cystine

\begin{tabular}{|c|c|c|c|c|c|c|c|}
\hline \multirow{3}{*}{$\begin{array}{l}\text { Cystine } \\
\text { conc. }\end{array}$} & \multirow{3}{*}{$\begin{array}{l}\text { Periods of } \\
\text { time heated } \\
\text { at } 50^{\circ} \mathrm{C}\end{array}$} & \multicolumn{3}{|c|}{ Experiment $1^{\text {a) }}$} & \multicolumn{3}{|c|}{ Experiment $2^{b}$} \\
\hline & & \multicolumn{2}{|c|}{$\log _{10} \mathrm{PFU} / \mathrm{cc}^{\mathrm{c})}$} & \multirow{2}{*}{$\begin{array}{l}\mathrm{R} / \mathrm{V} \\
\text { ratio }\end{array}$} & \multicolumn{2}{|c|}{$\log _{10} \mathrm{PFU} / \mathrm{cc}^{\mathrm{c})}$} & \multirow{2}{*}{$\begin{array}{l}\mathrm{R} / \mathrm{V} \\
\text { ratio }\end{array}$} \\
\hline & & Virus & RNA & & Virns & RNA & \\
\hline \multirow{3}{*}{$100 \mu \mathrm{g} / \mathrm{cc}$} & unheated & 7.7 & $\mathrm{ND}^{\mathrm{d})}$ & & 8.7 & $\mathrm{ND}$ & \\
\hline & 4 hrs. & 7.1 & 3.1 & -4.0 & & & \\
\hline & $6 \mathrm{hrs.}$ & 6.7 & 3.1 & -3.6 & 7.7 & 4.3 & -3.4 \\
\hline \multirow{4}{*}{ none } & unheated & 7.7 & 3.7 & -4.0 & 8.9 & 5.8 & -3.1 \\
\hline & "I & 7.2 & 3.4 & -3.8 & & & \\
\hline & 2 minutes & 6.3 & 2.2 & -4.1 & 7.4 & 4.2 & -3.2 \\
\hline & 30 minutes & 2.2 & 1.0 & -1.2 & & & \\
\hline
\end{tabular}

a) Exp. 1: Mahoney virus stock which was prepared in cystine-deficient 199 synthetic medium was used.

b) Exp. 2: The stock virus fluids were subjected to ultracentrifugation for 90 minutes at $30,000 \mathrm{rpm}$, the pellet was suspended in a small volume of phosphate buffer and the infectious RNA was extracted.

c) The virus and RNA were diluted with $2 \mathrm{M} \mathrm{MgSO}_{4}$ and infectivity was titrated on MS cell monolayers.

d) ND : not done.

was diluted with an equal volume of $0.02 \mathrm{M}$ phosphate buffer supplemented with $5 \times$ $10^{-4} \mathrm{M}$ tris buffer and then respective viral RNA was extracted. The infectivity of extracted RNA preparations and their original viruses was titrated after the method described in Materials and Methods. The efficiency of the extraction of infectious RNA was expressed by the ratio of the infectivity of RNA to that of the original intact virus $(R / V$ ratio).

Table 1 shows the results obtained for the comparison of $\mathrm{R} / \mathrm{V}$ ratio of various samples heated with or without cystine. The infectivity of the RNA preparation extracted from the unheated virus was $10^{3.7}$ and $10^{3.4} \mathrm{PFU} / \mathrm{cc}$ in Experiment 1 and $10^{5.8} \mathrm{PFU} / \mathrm{cc}$ in 
Experiment 2, showing $\mathrm{R} / \mathrm{V}$ ratios of $10^{-4.0}$ and $10^{-3.8}$ in the first experiment and $10^{-3.3}$ in the second experiment. When the virus was heated with $100 \mu \mathrm{g} / \mathrm{cc}$ of cystine at $50^{\circ} \mathrm{C}$ for 4 to 6 hours, a slight loss of infectivity (0.6 to $1.0 \log _{10} \mathrm{PFU} / \mathrm{cc}$ ) was observed, which was also reflected in a parallel drop in infectivity of the extracted RNA. Consequently, $\mathrm{R} / \mathrm{V}$ ratio of the heated virus with cystine remained unchanged. On the contrary, when the virus was heated without cystine, inactivation proceeded rapidly and after 30 minutes the infectivity dropped to $1 / 100,000$. When RNA extraction was attempted with these inactivated virus samples, it was found that the samples heated for 2 minutes at $50^{\circ} \mathrm{C}$ without cystine reduced its infectivity by $1.5 \log _{10} \mathrm{PFU} / \mathrm{cc}$ in parallel with the decrease in infectious RNA at the same rate. When the virus was heated for 30 minutes, the infectivity dropped to $10^{2.2} \mathrm{PFU} / \mathrm{cc}$. Considering the extraction efficiency of RNA from intact poliovirus $\left(\mathrm{R} / \mathrm{V}\right.$ ratio in the range of $10^{-3}$ to $10^{-4}$ ), the residual infectivity of $10^{2.2} \mathrm{PFU} / \mathrm{cc}$ is too low for the positive extraction of infectious RNA from this sample. However, the infectious RNA of $10 \mathrm{PFU} / \mathrm{cc}$ was actually extracted. The extraction of infectious RNA from the Mahoney virus heated at $50^{\circ} \mathrm{C}$ for 30 minutes was not regularly successful, but the fact was confirmed by another test. This will be discussed later.

\section{Efficiency of Plating of the Heated Poliovirus}

In the experiments described above the titration of intact or heated virus and of infectious RNA was carried out in the same manner, inoculating $0.2 \mathrm{cc}$ of diluted virus or RNA in $2 \mathrm{M} \mathrm{MgSO}_{4}$ onto MS cell monolayers. The extractability of infectious RNA from the material of such a low infectivity as $10^{2.2} \mathrm{PFU} / \mathrm{cc}$ led the authors to examine the efficiency of plating of the heated poliovirus on MS cell monolayers compared with the plaque formation on primary monkey kidney cultures. Table 2 shows the comparative titration of heated poliovirus under different conditions as specified in the table. Unheated intact virus and the virus heated with cystine $(100 \mu \mathrm{g} / \mathrm{cc})$ were also titrated in parallel. As seen in the table, intact virus showed comparable titers in both MS cells and primary monkey kidney cells. Similar results were obtained with the virus heated

Table 2. Efficiency of plating of the heated virus under three different conditions

\begin{tabular}{|c|c|c|c|c|}
\hline \multicolumn{2}{|c|}{ Condition for plating } & A & $\mathrm{B}$ & $\mathrm{C}$ \\
\hline \multicolumn{2}{|c|}{ Cell monolayers used } & MS cells & MK cells & MS cells \\
\hline \multicolumn{2}{|c|}{ Diluent for virus } & $2 \mathrm{M} \mathrm{MgSO}_{4}$ & P. B. S. & P. B. S. \\
\hline \multicolumn{2}{|c|}{ Adsorption period } & $20 \mathrm{~min}$ & $60 \mathrm{~min}$. & $60 \mathrm{~min}$. \\
\hline \multirow{2}{*}{$\begin{array}{l}\text { Cystine } \\
\text { conc. }\end{array}$} & Unheated virus ${ }^{a)}$ & $7.7^{\mathrm{c})}$ & 7.8 & \\
\hline & $2 \mathrm{~min}$. heated virus ${ }^{\mathbf{b})}$ & 6.3 & 6.6 & \\
\hline \multirow{2}{*}{$0 \mu \mathrm{g} / \mathrm{cc}$} & $30 \mathrm{~min}$ & 2.2 & 3.2 & 3.1 \\
\hline & 4 hrs. & $<1.0$ & 1.7 & 1.7 \\
\hline $100 \mu \mathrm{g} / \mathrm{cc}$ & $6 \mathrm{hrs}$. & 6.7 & 6.9 & \\
\hline
\end{tabular}

a) Mahoney virus prepared with cystine-difficient 199 synthetic medium was used.

b) The viruses were heated at $50^{\circ} \mathrm{C}$.

c) The titer of virus is expressed by $\log _{10} \mathrm{PFU} / \mathrm{cc}$. 
with cystine $(100 \mu \mathrm{g} / \mathrm{cc})$ at $50^{\circ} \mathrm{C}$ for 6 hours, and the virus heated without cystine at the same temperature for only 2 minutes. However, the poliovirus heated without cystine at $50^{\circ} \mathrm{C}$ for 30 minutes showed different PFU depending on the method of inoculation, i.e. about 10 times more plaques were produced by the inoculum diluted with phosphate-buffered saline (conditions $\mathrm{B}$ and $\mathrm{C}$ in Table 2) than by the inoculum diluted with $2 \mathrm{M} \mathrm{MgSO}_{4}$ (condition A in Table 2).

If the above described data are taken into account for the evaluation of the $\mathrm{R} / \mathrm{V}$ ratio of the poliovirus sample heated at $50^{\circ} \mathrm{C}$ for 30 minutes without cystine (Table 1 ; Experiment 1, the last line), a corrected value of the residual infectivity would be $10^{3.2}$ $\mathrm{PFU} / \mathrm{cc}$, and the $\mathrm{R} / \mathrm{V}$ ratio would be $10^{-2.2}$. This will still indicate that the $\mathrm{R} / \mathrm{V}$ ratio of this sample is significantly higher than those of intact virus specimens. Some interpretation of this fact will be discussed later.

\section{Thermal Sensitivity of Infectious RNA Extracted from Unheated Virus}

As it has been found that Mahoney strain was highly sensitive to thermal inactivation in the absence of cystine, thermal sensitivity of extracted RNA from this virus was examined. Four hundred $\mathrm{cc}$ of stock virus was subjected to ultracentrifugation for 90 minutes at 30,000 r.p.m. The pellet was suspended in a small volume of phosphate buffer, and its unheated aliquot was used for RNA extraction. The infectivity of the concentrated poliovirus was $10^{8.9} \mathrm{PFU} / \mathrm{cc}$, from which infectious RNA containing $10^{5.8}$ $\mathrm{PFU} / \mathrm{cc}$ was extracted. When this infectious RNA specimen was heated at $50^{\circ} \mathrm{C}$ for 30 minutes in the absence of cystine, the infectivity remained unchanged. This result indicates that viral RNA is far more thermoresistant than intact virus particles.

\section{Thermoresistant Variants of Mahoney Strain}

The above-described experimental data indicated that the poliovirus heated without cystine is easily inactivated, while RNA extracted from intact virus particles is far more heat-resistant. It was thus elucidated that the heat-inactivation of poliovirus implicates the denaturation of protein structure of the outer coat of the virus, which is prevented by the combination with L-cystine. In the previous communication it was reported that the ratio of stabilizing effect of L-cystine on poliovirus against heat inactivation was a rather stable genetic entity, which was not changed after ordinary tissue culture or human passages. The following experiment was carried out to examine a possibility that poliovirus variants could be obtained, which have a different rate of the stabilizing effect of L-cystine compared with the parent virus, by alternating selective heatings and serial passages in monkey kidney tissue cultures with or without cystine. Type 1 poliovirus, strain LSc, 2ab, the attenuated vaccine strain (Sabin), was employed for this experiment, because of its high capacity to combine with cystine and the resulting great thermal stability.

Two different lines of serial passages were carried out. One line was passed as follows. Mixture of virus with $50 \mu \mathrm{g}$ of cystine at a final concentration was incubated for 12 hours at $37^{\circ} \mathrm{C}$, and then, was heated at $50^{\circ} \mathrm{C}$ for 6 hours. The first survivors were grown in primary monkey kidney cultures maintained with the modified 199 synthetic medium supplemented with only cystine so as to give the identical concentration to that contained in the heated mixture. In the other line almost the same procedures were adopted, except that no cystine was added in any processes of heating of virus and its 
passages in monkey kidney cultures. These procedures were repeated 10 times with both passage lines.

The sixth and the tenth survivors of both lines were grown in monkey kidney cells in cystine-free 199 medium to get the sixth and the tenth harvest fluids, respectively, with which the rate of thermostability given by cystine, $\mathrm{d}$ and $\mathrm{rct} / 40$ characters were examined. The samples were designated S-h-6p-cys $(+)$, S-h-10p-cys $(+)$, S-h-6p-cys $(-)$ and S-h-10p-cys (-).

The results are given in Figs. 1 and 2. The original parental virus (LSc, 2ab) was very thermosensitive without cystine, and its cystine-induced thermostability has increased proportionally to the concentration of the compound as reported previously. S-h-6p-cys $(+)$ strain has still retained the parental characters not only in the rate of thermostability given at different concentrations of cystine, but also in the $\mathrm{d}$ and $\mathrm{rct} / 40$ markers. After further passages, the same tests were carried out on S-h-10p-cys $(+)$. This strain showed a different character from the former. Even in the absence of cystine, it was considerably thermoresistant at $50^{\circ} \mathrm{C}$, and was less stabilized by cystine. However, d and rct/40 characters remained unchanged $\left(\mathrm{d}^{-}\right.$and $\left.\mathrm{rct} / 40^{-}\right)$, like the parental strain.

S-h-6p-cys $(-)$, obtained from the other series of passage, had already become thermoresistant in the absence of cystine, and its thermal inactivation curves in the presence of different concentrations of cystine were quite similar to those of S-h-10p-cys $(+)$, indicating that it was stabilized little by cystine. This was in striking contrast to the thermosensitive property of S-h-6p-cys $(+)$ which had undergone the same passages in monkey kidney cultures with cystine. But no change of other characters of S-h-6pcys (-) was observed. S-h-10p-cys $(-)$, obtained after four additional passages, was also similar to S-h-6p-cys $(-)$ and S-h-10p-cys $(+)$, except that only d character had changed from $d^{-}$to $d^{ \pm}$. An additional experiment revealed that S-h-8p-cys $(-)$had still retained its $\mathrm{d}^{-}$character, like the parental strain.

From these data, it was found that the thermoresistant variants with less reactivity to thermostabilizing action of cystine could be obtained from the type 1 attenuated Sabin vaccine strain, but they have still kept the parental character in respect of an in vitro genetic marker, rct/40, and that the presence of cystine seemed to make slow the selection of thermoresistant variants.

\section{DISCUSSION}

From the data of several experiments which were carried out for the elucidation of mechanism involved in the stabilizing action of cystine on poliovirus against thermal inactivation, the following evidences were obtained:

1) Type 1 poliovirus, strain Mahoney, could retain its infectivity undiminished, when it was heated with cystine at $50^{\circ} \mathrm{C}$ for a considerably long period of time, and the RNA extractable from the heated virus also showed the same level of infectivity in terms of $\mathrm{R} / \mathrm{V}$ ratio as that extracted from intact virus.

2) The infectious RNA extracted from unheated virus was resistant against heating at $50^{\circ} \mathrm{C}$ for 30 minutes, whereas heating of virus without cystine under the same conditions resulted in a ten-thousandfold decrease in infectivity.

3) When RNA was extracted from heated poliovirus without cystine, which contained a small fraction of survival virus, more infectivity was recovered than that expected by an extraction factor of infectious RNA from intact virus.

The data might indicate that the protection of viral protein by cystine from heat- 


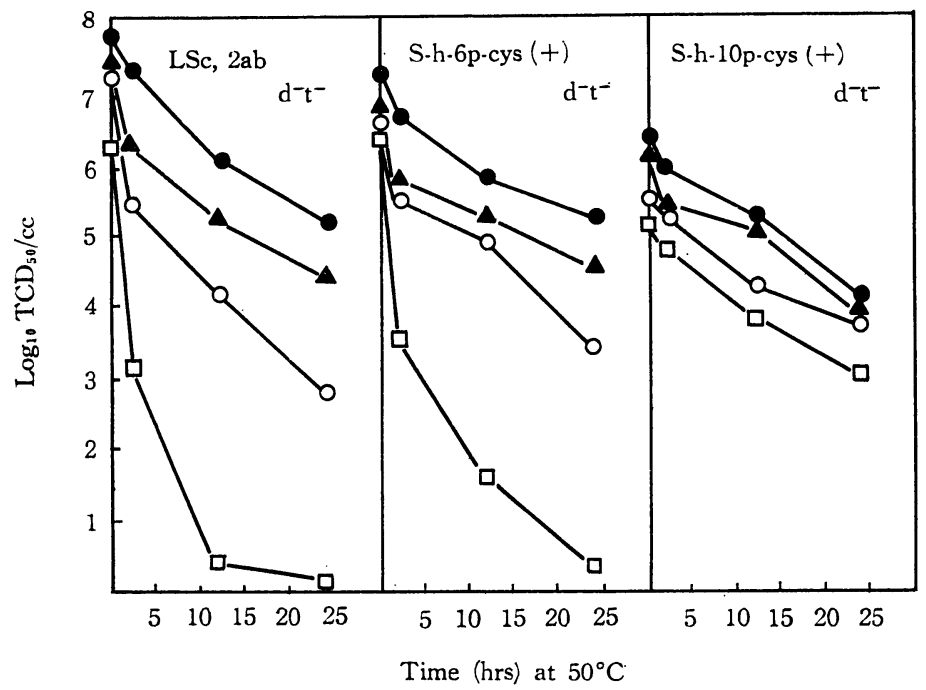

$100 \mu \mathrm{g}$ of cystine per cc. without cystine. $\mathrm{t}^{-}=\mathrm{rct} / 40^{-}$.

Fig. 1. Comparison of the thermal inactivation at $50^{\circ} \mathrm{C}$ of the parent line and the variants from six and ten successive survivor passages and reheating with cystine of type $1 \mathrm{LSc}, 2 \mathrm{ab}$ strain. Viruses were stabilized by incubating with cystine at $100 \mu \mathrm{g}, 50 \mu \mathrm{g}$ and $25 \mu \mathrm{g}$ per cc for 12 hours at $37^{\circ} \mathrm{C}$, and were heated for 24 hours at $50^{\circ} \mathrm{C}$.

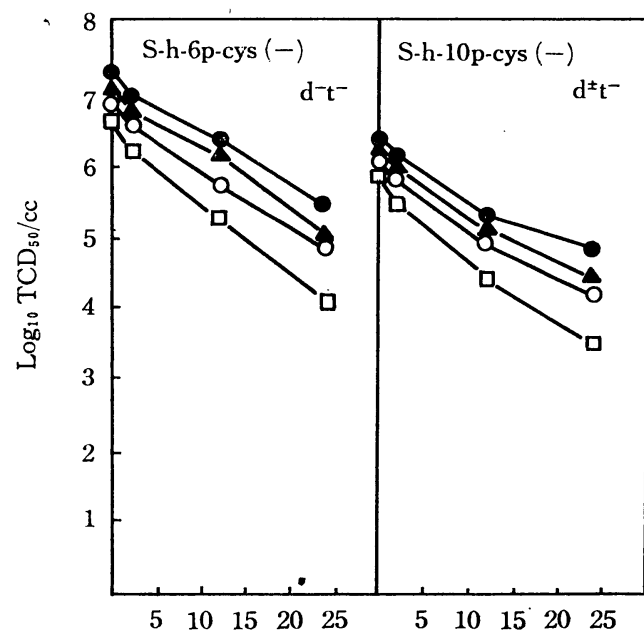

Time (hrs) at $50^{\circ} \mathrm{C}$

$100 \mu \mathrm{g}$ of cystine per cc of mixture.

$\Delta \longrightarrow \Delta 50 \mu \mathrm{g} . \quad \bigcirc-\bigcirc 25 \mu \mathrm{g} . \quad \square-\square$ without cystine.

Fig. 2. Comparison of the thermal inactivation at $50^{\circ} \mathrm{C}$ of variants from six and ten successive survivor passages and reheating without cystine of type 1 LSc, 2ab strain. Viruses were stabilized by incubating with cystine at $100 \mu \mathrm{g}$, $50 \mu \mathrm{g}$ and $25 \mu \mathrm{g}$ per cc for 12 hours at $37^{\circ} \mathrm{C}$, and were heated for 24 hours at $50^{\circ} \mathrm{C}$. 
denaturation was essential for the retention of infectivity of poliovirus, because infectious RNA extracted from virus particles proved to resist heating at $50^{\circ} \mathrm{C}$ for 30 minutes, which was found to destroy more than $99.99 \%$ of infectivity, when the intact virus was heated without cystine. A similar conclusion concerning thermostability of poliovirus RNA itself at a high temperature has already been reported by Holland et al. (1960) and more recently by Gordon et al. (1963), who have tested the thermal sensitivity of poliovirus RNA at higher temperatures.

When infectious RNA was extracted from the survivors of poliovirus heated without cystine at $50^{\circ} \mathrm{C}$ for 30 minutes, which showed a residual infectivity of $10^{2.2} \mathrm{PFU} / \mathrm{cc}$, the RNA preparation was found to have an infectivity of $10^{1.0} \mathrm{PFU} / \mathrm{cc}$. The ratio of infectivity of RNA versus that of virus suspension ( $\mathrm{R} / \mathrm{V}$ ratio) in this case was $10^{-1.2}$, which was greater than $\mathrm{R} / \mathrm{V}$ ratio obtained with intact virus and its infectious RNA. It was also found that Mahoney virus heated without cystine at $50^{\circ} \mathrm{C}$ for 30 minutes had a low efficiency of plating when inoculated in $2 \mathrm{M} \mathrm{MgSO}_{4}$ onto MS Cells, while it showed one $\log _{10}$ higher infectivity when inoculated in PBS onto MS cells or monkey kidney cells. It is not clear whether the low efficiency of plating of heated poliovirus was due to hypertonic $\mathrm{MgSO}_{4}$ solution used as a diluent of the inoculum or a short period of adsorption (20 minutes), which might have been insufficient for the heated virus to be adsorbed onto MS cells at the same efficiency as with intact virus. A similar finding was also noticed by Nakano (1962) in our laboratory during a study on the stabilizing effect of hypertonic $\mathrm{MgCl}_{2}$ solution on $\mathrm{ECHO}$ viruses against heating at $55^{\circ} \mathrm{C}$.

It is well established that moderate heat treatment liberates the nucleic acid of poliovirus with a concomitant change in complement-fixing antigenicity of the protein coat of the virus particle from $\mathrm{D}$ (type-specific) to $\mathrm{C}$ (common). When a virus suspension of high infectivity is heated, it is probable that liberated RNA would cause a certain change in viscosity and chemical composition of the menstruum. It appears to be likely that this change might account for a low efficiency of plating, when the heated virus suspension was further diluted with a hypertonic $\mathrm{MgSO}_{4}$ solution. It is also likely from the data of the present experiments that heating at $50^{\circ} \mathrm{C}$ for 30 minutes can destroy the infectivity of a portion of the virus particles without affecting the internal RNA. A similar observation was reported by Cooper (1963). A possible explanation for this fact might be that the change in the composition of the menstruum by the liberation of RNA of the major portion of the virus particles might have prevented further liberation of RNA, although the destruction of infectivity proceeded gradually.

The procedures of alternating selective heatings with passages in tissue culture have often been employed for the selection of thermoresistant variants (Youngner, 1957: Dubes, 1960 : Papaevangeltou et al., 1961: Wallis et al., 1963). It is of interest to examine the biological properties of the variants selected by the procedure. As described above, any particular variation has not been observed except that they have become thermoresistant. The presence of cystine seems to play an inhibitory effect on the selection of thermoresistant variants. This fact is considered to be due to the increased survival rate of phenotypic thermoresistant viruses combined with cystine in the cystine group, while real thermoresistant mutants have more chance to be selected by the selective heating in the cystine-free group. Dubes et al. (1960) and Pohjanpelto (1961) have reported the fact that the genetic thermoresistant property of poliovirus accompanied with low response to the thermostabilizing action of cystine. Our finding was also in concord with their results. 
Dubes et al. (1957, 1958, 1960) and McBride (1962) have demonstrated another biological significance of L-cystine to poliovirus in regard to the growth requirement of poliovirus for cystine. Several poliovirus mutants with altered requirement for cystine in their intracellular replication had been isolated by them, and their biological characters have been examined. In the present experiments, no study designed to obtain a mutant with altered growth requirement for cystine has been carried out. The fact that the thermoresistant variants selected from the thermosensitive vaccine strain have still retained the $\mathrm{t}^{-}(\mathrm{rct} / 40), \mathrm{d}^{-}$or $\mathrm{d}^{ \pm}$characters, will indicate that the in vitro characters more or less related to neurovirulence of the attenuated vaccine strain are so stable as not to be altered by the simple heating of virus particles. A similar result was reported by Papaevangeltou (1961) while our experiments were being carried out.

\section{SUMMARY}

The infectious RNA extracted from Mahoney strain was resistant to heating at $50^{\circ} \mathrm{C}$ for 30 minutes, whereas heating of virus without cystine for the same period resulted in a ten thousand-fold decrease in infectivity. The virus with cystine even after heating at $50^{\circ} \mathrm{C}$ for a considerable long period of time retained its infectivity undiminished. Therefore, it might be reasonable to consider that the thermal stabilizing effect of L-cystine on poliovirus is due to the protection of the virus particle from the denaturation of surface protein by heating.

The thermoresistant variants were selected from the thermosensitive vaccine strain by alternating selective heatings and passages of virus in monkey kidney tissue cultures with or without cystine. The presence of cystine lowered the efficiency of the selection of such variants. The variants obtained have retained the parental characters in respect of $\mathrm{d}$ and $\mathrm{rct} / 40$ markers.

\section{REFERENCES}

Alexander, H. E., Koch, G., Mountain, I. M. \& Van Damme, O. (1958) : Infectivity of ribonucleic acid from poliovirus in human cell monolayer. J. Exper. Med., 108, 493-506.

COOPER, P. D. (1962) : Studies on the structure and function of the poliovirion; Effect of concentrated urea solutions. Virology, 16, 485-495.

DuBES, G. R. \& WenNeR, H. A. (1957) : Virulence of polioviruses in relation to variant characteristics destinguishable on cells in vitro. Virology, 4, 275-296.

DuBES, G. R. \& ChApIN, M. (1958) : Poliovirus mutants with altered responses to cystine. J. Gen. Microbiol., 18, 320-329.

Dubes, G. R., Chapin, M. \& Tolbert, O. (1960) : The genetic relationship between thermostability of poliovirus and its in vivo response. Arch. ges. Virusforch., 10, 315-334.

Gordon, M. P., HufF, J. W. \& Holland, J. J. (1963) : Heat inactivation of the infectious ribonucleic acids of polio and tobacco mosaic viruses. Virology, 19, 416-418.

Holland, J. J., Hoyer, B. H., Mclaren, L. C. \& Syverton, J. T. (1960) : Enteroviral ribonucleic acid. I. Recovery from virus and assimilation by cells. J. Exper. Med., 112, 821-839.

Holland, J. J., McLaren, L. C., Hoyer, B. H. \& Syverton, J. T. (1960) : Enteroviral ribonucleic acid. II. Biological, physical and chemical studies. J. Exper. Med., 112, 841864.

Ikegami, N., Yoshikawa, E. \& TAgaya, I. (1963) : The stabilizing effect of L-cystine on the thermal inactivation of poliovirus. I. The available methods for differentiating the strains of poliovirus by heating with L-cystine. Jap. J. M. Sc. \& Biol., 16, 325-342. 
MCBRIDE, M. D. (1962) : Biological significance of poliovirus mutants of altered cystine requirement. Virology, 18, 118-130.

NAKANO, M. (1962) : Personal communication.

Papaevangeltou, G. J. \& Youngner, J. S. (1961): Thermal stability of ribonucleic acid from poliovirus mutants. Virology, 15, 509-510.

Papaevangeltou, G. J. \& Youngner, J. S. (1961): Correlation between heat-resistance of polioviruses and other genetic markers. Proc. Soc. Exper. Biol. \& Med., 108, 505-507.

POHJANPelto, P. (1958): Stabilization of poliovirus by cystine. Virology, 6, 472-487.

POHJANPElto, P. (1951): Two different termostable variants of poliovirus. Virology, 15, 231-236.

TOlBERT, O. \& DuBES, G. R. (1961) : Efficiency of plating certain poliovirus on tissue cultures at higher temperatures as a function of L-cystine concentration. Proc. Soc. Exper. Biol. \& Med., 108, 412-416.

YOUNGNER, J. S. (1957): Thermal inactivation studies with different strains of poliovirus. J. Immunol., 78, 282-290. 